DOI 1052646

\title{
GAMBARAN PENGETAHUAN PERAWAT TENTANG KEDARURATAN PSIKIATRI DI RUMAH SAKIT JIWA DAERAH ABEPURA
}

\author{
Mariam M S Bano', Muhamad Rhomandoni ${ }^{2}$, Sudarsono ${ }^{3}$, Rifki S Nompo ${ }^{4}$ \\ ${ }^{1}$ Rumah Sakit Jiwa Daerah Abepura - Papua \\ ${ }^{2}$ LPMP (Lembaga Penjaminan Mutu Pendidikan) Kota Raja \\ ${ }^{3}$ Prodi Pendidikan Profesi Ners STIKES Jayapura \\ email: mariamsbano@gamil.com
}

\begin{abstract}
ABSTRAK
Latar Belakang: Penyakit kejiwaan yang berhubungan dengan masalah kedarurtan psikiatri adalah depresi, bipolar, skizofrenia dan psikosis lainnya, demensia. Kedaruratan psikiatri adalah gangguan pikiran, perasaan, atau perilaku yang membutuhkan intervensi terapeutik segera. Masalah yang dapat terjadi akibat kondisi kedaruratan psikiatri yaitu perilaku kekerasan, bunuh diri, delirium dan sindrom neuroleptik maligna. Saat ini di dunia terdapat lebih dari 264 juta orang terkena depresi, 45 juta orang terkena bipolar, 20 juta orang terkena skizofrenia dan psikosis lainya, 50 juta orang terkena demensia.Tujuan penelitian: Dapat mengetahui gambaran pengetahuan perawat tentang kedaruratan psikiatri di Rumah Sakit Jiwa Daerah Abepura. Metode penelitian: Jenis penelitian ini adalah deskriptif kuantitatif, populasi adalah seluruh perawat di Rumah Sakit Jiwa Daerah Abepura yaitu 135 perawat dan tekinik pengambilan sampel menggunakan rumus solvin sehingga jumlah sampel adalah 101 perawat. Instrument yang digunakan adalah kuesioner pengetahuan perawat tentang kedaruratan psikiatri yang telah di uji validitas dan reliabilitas dengan hasil uji kuesioner telah valid dan reliabel. Hasil: Karakteristik responden mayoritas umur kurang dari $(<) 40$ tahun $(89.1 \%)$, jenis kelamin perempuan $(72.3 \%)$, lama kerja kurang dari $(<) 5$ tahun $(61.4 \%)$, pendidikan D III keperawatan $(71.3 \%)$. Dari 101 perawat 38 perawat memiliki kategori pengetahuan baik (37.6\%), 45 perawat memiliki kategori pengetahuan cukup (37.6\%) dan 18 perawat memiliki kategori pengetahuan kurang (17.8\%). Kesimpulan: Mayoritas perawat di Rumah Sakit Jiwa Daerah Abepura memiliki pengetahuan cukup (37.6\%) tentang kedaruratan psikiatri.
\end{abstract}

Kata kunci: Kedaruratan psikiatri, Pengetahuan, Perawat.

\begin{abstract}
Intoduction: Psychiatric illnesses associated with psychiatric emergencies are depression, bipolar disorder, schizophrenia and other psychoses, dementia. A psychiatric emergency is a disorder of thought, feeling, or behavior that requires immediate therapeutic intervention. Problems that can occur due to psychiatric emergencies include violent behavior, suicide, delirium and neuroleptic malignant syndrome. Currently in the world there are more than 264 million people affected by depression, 45 million people affected by bipolar disorder, 20 million people affected by schizophrenia and other psychosis, 50 million people affected by dementia. The Aim: To find a description of the knowledge of nurses about psychiatric emergencies at Regional Mental Hospitals Abepura. Method: This type of research is quantitative descriptive, the population is all nurses in Abepura Mental Hospital, namely 135 nurses and the sampling technique uses the solvin formula so that the number of samples is 101 nurses. The instrument used was a questionnaire about nurses' knowledge of psychiatric emergencies which had been tested for validity and reliability, with the results of the questionnaire being valid and reliable. Results: Characteristics of the majority of respondents were less than $(<) 40$ years old (89.1\%), female gender (72.3\%), length of work was less than (<) 5 years (61.4\%), D III nursing education (71.3\%). Of the 101 nurses, 38 nurses had a good knowledge category (37.6\%), 45 nurses had sufficient knowledge (44.6\%) and 18 nurses had a poor
\end{abstract}




\section{Mariam M S Bano: Gambaran Pengetahuan Perawat Tentang Kedaruratan Psikiatri Di Rumah Sakit Jiwa Daerah Abepura}

knowledge category (17.8\%). Conclusion: The majority of nurses at Abepura Regional Mental Hospital are knowledgeable (37.6\%) about psychiatric emergencies.

Keywords: Psychiatric emergency, Knowledge, Nurse

\section{PENDAHULUAN}

Penyakit kejiwaan World Health Organization (2019) yang berhubungan dengan masalah kedarurtan psikiatri adalah depresi, bipolar, skizofrenia dan psikosis lainnya, demensia. Kedaruratan psikiatri adalah gangguan pikiran, perasaan, atau perilaku yang membutuhkan intervensi terapeutik segera. Masalah yang dapat terjadi akibat kondisi kedaruratan psikiatri yaitu perilaku kekerasan, bunuh diri, delirium dan sindrom neuroleptik maligna (Elvira \& Hadisukanto, 2013). Saat ini di dunia terdapat lebih dari 264 juta orang terkena depresi, 45 juta orang terkena bipolar, 20 juta orang terkena skizofrenia dan psikosis lainya, 50 juta orang terkena demensia (WHO, 2019).

Di Provinsi Papua prevalensi penduduk umur lebih dari atau sama dengan 15 tahun mengalami depresi $4,0 \%$, prevalensi rumah tangga dengan ART yang mengalami skizofrenia atau psikiosis lainnya $4,5 \%$, dan prevalensi penduduk umur lebih dari atau sama dengan 15 tahun mengalami gangguan mental emosional $8.5 \%$.

Seseorang beresiko tinggi untuk melakukan tindakan kekerasan baik pada diri sendiri, orang lain, maupun lingkungannya jika kondisi kedaruratan psikitari tidak segarah ditangani (Oktaviani., dkk, 2019). Perawat merupakan tenaga profesional kesehatan yang paling dekat dengan pasien, tugasnya adalah memberikan pelayanan prima dan terbaru untuk pasien dalam bentuk asuhan keperawatan membutuhkan kemampuan, ketrampilan dan pengetahuan (Putri, 2016). Asuhan keperawatan adalah rangkaian interaksi perawat dengan klien dan lingkungannya untuk mencapai tujuan pemenuhan kebutuhan dan kemandirian klien dalam merawat dirinya (Febriana, 2017). Penilaian dan menajemen pasien dengan keadaan darurat psikiatri adalah aspek penting dalam memberikan perawatan darurat (Pratiwi., dkk, 2017).
Dari hasil pangambilan data awal di Rumah Sakit Jiwa Daerah Abepura Povinsi Papua pada bulan maret tahun 2020, diperoleh data tahun 2019 jumlah pasien gangguan jiwa adalah 7.432 jiwa dengan kasus kedaruratan psikiatri yaitu perilaku kekerasan sebanyak 1.387 pasien, percobaan bunuh diri sebanyak 5 pasien, Sindrom Neuroleptik Maligna 1.756 pasien, delirum 4 pasien. Jumlah perawat per maret 2020 adalah 135 perawat dimana hampir semua perawat merupakan perawat dengan jenjang pendidikan sebagai perawat umum dan hanya 5 orang perawat khusus jiwa. Menurut pengamatan peneliti terhadap 135 perawat didapati bahwa pengetahuan perawat tentang kedaruratan psikiatri di Rumah Sakit Jiwa Daerah Abepura adalah 45 perawat tahu sedangkan 85 perawat kurang tahu dan hasil wawancara dengan 5 perawat terdapat 4 perawat kurang tahu dan 1 perawat tahu.

Berdasarkan uraian masalah diatas peneliti tertarik untuk melakukan penelitian mengenai Gambaran Pengetahuan Perawat Tentang Kedaruratan Psikiatri di Rumah Sakit Jiwa Daerah Abepura Provinsi Papua.

\section{METODE PENELITIAN}

Penelitian ini adalah penelitian deskriptif kuantitatif! penelitian deskriptif adalah penelitian yang dilakukan untuk menggambarkan fenomena atau keadaan secara objektif, tidak ada kelompok kontrol atau pembanding, tidak mencari penyebab masalah, merancang cara pendekatan meliputi macam data, penentuan sampel hingga penyajian data, serta menyusun laporan (Putri, 2016).

Jumlah Populasi adalah 135 perawat, populasi merupakan keseluruan jumlah yang terdiri atas objek atau subjek yang mempunyai karakteristik dan kualitas tertentu yang ditetapkan oleh peniliti dan kemudian ditarik kesimpulannya (Sujarweni, 2014). Penentuan jumlah sampel dari populasi 135 dengan taraf 
kesalahan $5 \%$ menggunakan rumus solvin (Siregar, 2017) yaitu 101. Intrumen yang digunakan dalam penelitian ini diantaranya yaitu kuesioner karaktersitik responden dan kuesioner pengetahuan perawat tentang kedaruratan psikiatri.

Instrumen pengetahuan perawat tentang kedaruratan psikiatri yang digunakan telah di uji validitas dan reliabelitas menggunakan analisis statistik korelasi product moment dimana nilai $\alpha$ $=0.05$. Hasil uji instrumen telah valid dan reliabel karena nilai $\mathrm{r}_{\text {hitung }}(0.754)>\mathrm{r}_{\text {table }}(0.361)$ dengan nilai mean pada hasil uji validitas instrument adalah 0.437 .

\section{HASIL PENELITIAN}

Hasil penelitian ini menggunakan analisis univariat terhadap distribusi frekunesi karakteristik responden dan presentase satu variabel.

\section{Karakteristik responden}

Tabel 4.1 Distribusi Frekuensi Karakteristik Responden

\begin{tabular}{lcc}
\hline Karakteristik & $\begin{array}{c}\text { Frekuensi } \\
\text { (f) }\end{array}$ & $\begin{array}{c}\text { Presentase } \\
(\%)\end{array}$ \\
\hline Umur & & \\
a. > 40 Tahun & 11 & 10.9 \\
b. < 40 Tahun & 90 & 89.1 \\
Total & 101 & 100 \\
\hline Jenis Kelamin & & \\
a. Laki - laki & 28 & 27.7 \\
b. Perempuan & 73 & 72.3 \\
Total & 101 & 100 \\
\hline Lama Kerja & & \\
a. > 5 Tahun & 39 & 38.6 \\
b. < 5 Tahun & 62 & 61.4 \\
Total & 101 & 100 \\
\hline Pendidikan & & \\
a. D-III & 72 & 71.3 \\
b. D IV & 2 & 2 \\
c. S1 Ners & 27 & 26.7 \\
Total & 101 & 100 \\
\hline
\end{tabular}

Data pada tabel 4.1 distribusi frekuensi karakteristik responden berdasarkan umur diketahui bahwa perawat umur lebih dari (>) 40 tahun sebanyak 11 responden $(10.9 \%)$ dan umur kurang dari (<) 40 tahun sebanyak 99 responden $(89.1 \%)$. Hal ini menunjukan bahwa mayoritas umur responden adalah umur kurang dari (>) 40 tahun 99 responden $(89.1 \%)$.

Berdasarkan jenis kelamin diketahui bahwa perawat jenis kelamin laki - laki sebanyak 28 responden $(27.7 \%)$ dan jenis kelamin perempuan sebanyak 73 responden (72.3\%). Hal ini menunjukan bahwa mayoritas jensi kelamin responden adalah jenis kelamin perempuan 73 responden $(72.3 \%)$.

Berdasarkan lama kerja diketahaui bahwa perawat lama kerja lebih dari (>) 5 tahun sebanyak 39 responden $(38.6 \%)$ dan perawat lama kerja kurang dari $(<) 5$ tahun sebanyak 62 reponden $(61.4 \%)$. Hal ini menunjukan bahwa mayoritas responden lama kerja adalah lama kerja kurang dari (>) 5 tahuan 62 responden $(61.4 \%)$.

Berdasarkan Pendidikan diketahui bahwa perawat pendidikan D III sebanyak 72 responden $(71.3 \%)$, perawat pendidikan D IV sebanyak 2 responden $(2 \%)$ dan perawat pendidika S1 Ners sebanyak 27 responden (26.7 $\%)$. Hal ini menunjukan bahwa mayoritas pendidikan responden adalah pendidikan D-III keperawatan 72 responden $(71.3 \%)$.

Tabel 4.2 Gambaran pengetahuan perawat tentang kedaruratan psikiatri

\begin{tabular}{lcc}
\hline Kategori & Frekuensi (f) & Presentase $(\%)$ \\
\hline Baik & 38 & 37.6 \\
Cukup & 45 & 44.6 \\
Kurang & 18 & 17.8 \\
Total & 101 & 100 \\
\hline
\end{tabular}

Pada tabel 4.2 gambaran pengetahuan perawat tentang kedaruratan psikaitri di Rumah Sakit Jiwa Daerah Abepura menunjukan bahwa dari 101 perawat diantaranya 38 responden memiliki kategori pengetahuan baik $(37.6 \%), 45$ responden memiliki kategori pengetahuan cukup (44.6\%) dan 18 responden memiliki kategori pengetahuan kurang (17.8\%). Hal ini menunjukan bahwa mayoritas pengetahuan perawat memiliki kategori pengetahuan cukup $(44.6 \%)$

\section{PEMBAHASAN}

\section{Analisis Karakteristik Responden}

a. Umur

Karakteristik umur responden pada hasil penelitian ini menunjukan bahwa perawat 
umur lebih dari (>) 40 tahun lebih sedikit dari perawat umur kurang dari $(<) 40$ tahun. Menurut Mugito., dkk (2016) tenaga perawat pada usia kurang dari $(<) 40$ tahun merupakan aset bagi rumah sakit karena mempunyai kinerja dan produktifitas yang baik bagi pelayanan keperawatan, pada usia ini tenaga perawat mempunyai kematangan jiwa, lebih bijaksana dan berfikir lebih rasional. Menurut Siagian (2014) umur antara 21 - 40 tahun berada dalam tahap penjajakan dan pemantapan secara terus menerus melakukan pengujian terhadap kemampuan yang dimiliki dan mencoba untuk melakukan pekerjaan yang sesuai dengan minat dan bakatnya. Menurut Arisandy (2018) perbedaan usia mempunyai pengaruh yang berhubungan dengan adanya perbedaan pengalaman atau pengetahuan seseorang. Dapat diartikan bahwa pengetahuan seorang perawat dengan produktifitas usia penjanjakan dan pemantapan kinerja belum tentu memiliki penegtahuan yang baik karena kurangnya pengalaman sebagai salah satu faktor peningkatan pengetahuan.

b. Jenis kelamin

Perwat dengan jenis kelamin perempuan lebih banyak dari perawat jenis kelamin laki - laki. Menurut Hasby., dkk (2017) jumlah perawat perempuan yang lebih banyak dibanding perawat laki-laki disebabkan karena perawat identik dengan seseorang yang berjenis kelamin perempuan. Mengenai dominasi perempuan dalam keperawatan female dominated-occupation menyampaikan bahwa praktek keperawatan merupakan praktik yang berhubungan erat dengan persepsi mengenai gender, dipengaruhi dan didukung oleh tradisi dan budaya. Meskipun dalam menjalankan peran profesional seharusnya tidak mementingkan masalah gender, namun pesepsi mengenai dominasi perempuan pada dunia keperawatan memang masih kental (Hartiti dan Wulandari, 2018). Hal ini menujukan bahwa perbedaan jenis kelamin belum dapat dijadikan perberbedaan tingkat pengetahuan karena profesi keperawatan banyak didominasi oleh perempuan.

c. Lama kerja

Perawat lama kerja lebih dari (>) 5 tahun lebih sedikit dari pada perawat dengan lama kerja kurang dari (<) 5 tahun. Terjadinya peningkatan pengetahuan menurut penelitian Roffey Park Management Institute dipengaruhi oleh pengalaman, kemampuan utama yang termasuk di dalamnya adalah fleksibilitas, kreativitas, kemampuan berubah dan keinginan untuk terus belajar (Simanjuntak, 2011). Pengalaman dapat diperoleh dari lama kerja pada pengalaman sendiri maupun orang lain, pengalaman yang sudah diperoleh dapat memperluas pengetahuan seseorang (Pujiharti., dkk, 2017). Dapat diartikan bahwa perawat yang bekerja tegolong masih baru dalam mengembankan profesinya sebagai perawat memerlukan peningkatan pengetahuan melalalui pelatihan kedaruratan psikiatri.

d. Pendidikan

Perawat pendidikan D-III keperawatan lebih banyak dari perawat dengan tingkat pendidikan D IV keperawatan dan perawat pendidikan S1 Ners. Tingkat pendidikan yang bervariasi dari tingkat SPK, DIII, S1 Ners, Magister dan Spesialis mempengaruhi tingkat pengetahuan perawat (Yusuf., dkk, 2016). Menurut Yulianti., dkk (2016) melalui pendidikan seseorang akan mempelajari banyak hal, menyerap banyak informasi, mengubah persepsi dan membentuk pemahaman yang benar. Menurut Rizani., dkk, (2018) bahwa adanya keinginan dari perawat untuk memperbanyak ilmu dan pengetahuannya dengan cara melanjutkan pendidikannya kejenjang yang lebih tinggi dapat mempengaruhi pengetahuan seseorang termasuk juga perilaku seseorang akan pola hidup terutama dalam memotivasi untuk sikap berperan dalam peningkatan pelayanan keperawatan. Hal ini menujukan bahwa peningkatan pengetahuan melalui peningkatan pendidikan keperawatan menjadi sangat perlu guna meningkatkan pelayanan keperawatan secara khusus di bidang keperawatan jiwa.

\section{Analisa Gambaran Pengetahuan Perawat Tentang Kedaruratan Psikiatri}

Hasil penelitian pengetahuan perawat tentang kedaruratan psikiatri di Rumah Sakit Jiwa Daerah Abepura sebagian besar berada pada kategori pengetahuan cukup. Hasil ini tidak sejalan dengan Astuti (2017) pengetahuan perawat pada pelatihan terkait dengan manajemen kegawatdaruratan psikiatrik adalah $83 \%$ memiliki tingkat pengetahuan tinggi dan 
17\% memiliki tingkat pengetahuan sedang. Hasil ini juga tidak sejalan dengan Inoq (2017) bahwa mayoritas tingkat pengetahuan perawat tentang restrain dan tindakan pemasangan restrain pada pasien perilaku kekerasan dalam kategori baik $(88.9 \%)$. Pengetahuan perawat mempengaruhi hasil pelayanan kedaruaratan psikiatri diamana semakin baik tingkat penegtahuan kedaruratan psikiatri maka semakin baik hasil pelayanan yang diperoleh pasien dan masyarakat.

Menurut Budiman dan Riyanto (2013) faktor - faktor yang mempengaruhi pengetahuan adalah pendidikan, media masa/informasi, sosial budaya dan ekonomi, lingkungan, pengalaman, dan usia. Menurut Mawu., dkk (2016) bahwa semakin bertambah usia akan semakin berkembang pula daya tangkap dan pola pikirnya, sehingga pengetahuan yang diperolehnya semakin membaik. Menurut Syamsudin., dkk (2020) usia perawat memiliki pengaruh pada seberapa kuat mereka setuju dengan pentingnya faktor internal dalam mengontrol agresi pasien dan dengan menggunakan terapi medis dan pengekangan, bertambahnya usia perawat berbanding lurus dengan pengalaman dan lama kerja perawat akan semakin terlatih dan mempunyai strategi untuk bisa mengontrol agresi pasien dan mengontrol dirinya untuk bisa terapeutik terhadap pasien.

Ajauro., dkk (2019) mengungkapkan bahwa pendidikan merupakan salah satu faktor yang dapat memepengaruhi pengetahuan karena masing-masing jenjang memiliki perbedaan penegtahuan dan cara pandang. Menurut Widodo (2016) pengetahuan perawat tidak mutlak karena satu faktor tertentu namun di pengaruhi oleh berbagai faktor yang saling mempengaruhi baik usia, pendidikan, lama kerja pelatihan sebagai sumber informasi tambahan. Menurut Turangan., dkk (2017) pengetahuan yang baik dapat disebabkan oleh faktor lama kerja dari perawat bukan hanya tingkat pendidikan karena kurangnya motivasi saat mengikuti proses pembelejaran pendidikan formal. Menurut Apriluana., dkk (2016) pengalaman merupakan suatu gabungan antara pengetahuan dan perilaku seseorang dimana pengetahuan hasil dari tahu setelah orang melakukan penginderaan suatu objek tertentu sementara perilaku merupakan segala bentuk tanggapan dari individu terhadap lingkungannya, lamakerja identik dengan pengalaman, semakin lama kerja seseorang maka pengalamannya menjadisemakin bertambah. Pengalaman akan berpengaruh dalam meningkatkan pengetahuan seseorang, karena pengetahuan seseorang juga diperoleh dari pengalaman. Berbeda dengan Dharmawati dan Wirata (2016) bahwa makin tinggi pendidikan seseorang semakin tinggi pula mereka menerima informasi dan pada akhirnya makin banyak pula pengetahuan yang dimilikinya, sebaliknya jika seseorang tingkat pendidikannya rendah, akan menghambat perkembangan sikap seseorang terhadap penerimaan informasi. Hal ini dapat diartikan bahwa penegtahuan perawat tentang kedaruratan psikiatri dalam kategori cukup tidak ditentukan oleh sala satuh faktor namun perlu dilihat dari berbagai faktor yang mempengaruhinya.

Hasil penelitian ini memiliki keterbatasan karena:

a. Penelitian dilakukan pada masa pandemik Covid 19 dan jumlah sampel 101 orang dimana jumlah perawat jaga dibatasi setiap harinya sehingga penjelasan pengisian kuesioner dilakukan pada perawat perwakilan yang kemudian informasi diteruskan dan diserahkan kepeda setiap responden yang bersedia.

b. Penerapan social distencing mengharuskan peneliti membatasi waktu dalam mengawasi proses pengisian kuesioener secara langsung.

\section{KESIMPULAN}

Hasil penelitian gambaran pengetahuan perawat tentang kedaruratan psikiatri di Rumah Sakit Jiwa Daerah Abepura diketahui bahwa dari 101 responden diantaranya 38 responden perawat memiliki kategori pengetahuan baik (37.6 \%), 45 responden perawat memiliki kategori pengetahuan cukup (44.6\%) dan 18 responden perawat memiliki kategori pengetahuan kurang $(17.8 \%)$. Sebagian besar perawat memiliki kategori pengatahuan cukup.

\section{DAFTAR PUSTAKA}

Ajauro D. C., Anugrahini, C., \& Mau, D. T. (2019). Gambaran Tingkat Pengetahuan Perawat Dalam Mengidentifikasi Keselamatan Pasien di IGD RSUD mgr gabriel manek, svd Atambua Nusa 


\section{Mariam M S Bano: Gambaran Pengetahuan Perawat Tentang Kedaruratan Psikiatri Di Rumah Sakit Jiwa Daerah Abepura}

Tenggara Timur. Jurnal Sahabat Keperawatan, 1 (02), 89103. November 20, 2020. http://jurnal.unimor.ac.id

Apriluana, G., Khairiyati, L., \& Setyaningrum, R. (2016). Hubungan antara usia, jenis kelamin, lama kerja, pengetahuan, sikap dan ketersediaan alat pelindung diri $(A P D)$ dengan perilaku penggunaan $A P D$ pada tenaga kesehatan. Jurnal Publikasi Kesehatan Masyarakat Indonesia (JPKMI), 3(3), 82-87

Arisandy, W. (2018). Hubungan Karakteristik Perawat Dengan Tingkat Kecemasan Dalam Mengatasi Pasien Gaduh Gelisah Di Ruang Igd Dan Asoka Rumah Sakit Ernaldi Bahar Sumatera Selatan Palembang Tahun 2017. Gaster, 16 (1), 94-104. Oktober 8, 2020. http://jurnal.aiskauniversity.ac.id

Astuti, R. T. (2017, February). Peningkatan Kemampuan Manajemen Kedaruratan Psikiatrik: Panik Bagi Perawat Jiwa Di Rs Jiwa Gracia Yogyakarta. In Prosiding Seminar Nasional \& Internasional. Oktober 28, 2020. https://jurnal.unimus.ac.id.

Budiman \& Riyanto A. (2013). Kapita Selekta Kuesioner Pengetahuan Dan Sikap Dalam Penelitian Kesehatan. Jakarta: Salemba Medika

Dharmawati, I. G. A. A. (2016). Hubungan Tingkat Pendidikan, Umur, Dan Masa Kerja Dengan Tingkat Pengetahuan Kesehatan Gigi Dan Mulut Pada Guru Penjaskes Sd Di Kecamatan Tampak Siring Gianyar. Jurnal Kesehatan Gigi (Dental Health Journal), 4(1), 1-5.

Elvira, D.S., \& Hadisukanto, G. (2013). Buku Ajar Psikiatri. Jakarta: Badan Penerbit FKUI

Hartiti, T., \& Wulandari, D. (2018). Karakteristik Profesional Keperawatan Pada Mahasiswa Studi Ners Fikkes Universitas Muhammadiyah Semarang. Nurscope: Jurnal Keperawatan Pemikiran Ilmiah, 4(3), 72-79.

Hasby, M., Hendriani, S., \& Indarti, S. (2017). Pengaruh Konflik Kerja, Beban Kerja dan Komunikasi terhadap Stres Kerja Perawat Bagian Rawat Inap (pada
RSUD. Petala Bumi Pekanbaru) (Doctoral dissertation, Riau University). Novemver $\quad 17, \quad 2020$. https://media.neliti.com/media/publicatio ns/116708-ID-pengaruh-konflik-kerjabeban-kerja-dan-k.pdf

Inoq, F. (2017). Hubungan Pengetahuan Perawat Tentang Restrain Dengan Tindakan Pemasangan Restrain Pada Pasien Dengan Perilaku Kekerasan Di Unit Perawatan Intensif (UPI) Rumah Sakit Jiwa Grhasia Daerah Istimewa Yogyakarta (Doctoral dissertation, STIKES Jenderal Achmad Yani Yogyakarta). November 23, 2020 http://repository.unjaya.ac.id

Mugito, S., Aniroh, U., \& Wakhid, A. (2016). Hubungan Karakteristik Individu Dengan Perilaku caring Perawat di Rumah Sakit Jiwa Profdr. S. Oerojo Magelang. Oktober 30, 2020.

Mawu, D. P., Bidjuni, H., \& Hamel, R. (2016). Hubungan Karakteristik Perawat dengan Penanganan Pertama pada Pasien Kegawatan Muskuloskeletal di RSUP Prof. Dr. RD Kandou Manado. Jurnal Keperawatan, 4(2). November 20, 2020. file://C:/Users/User /App Data/Local/Temp/12917-25758-SM.pdf

Oktaviany, D. S., Arum Pratiwi, S. K., \& Rahayuningsih, F. B. (2019). Hubungan Karakteristik Personal Perawat Dengan Tingkat Pengetahuan Tentang Cara Penanganan Kegawatdaruratan Psikiatri Di Ruang Emergency (Doctoral dissertation, Universitas Muhammadiyah Surakarta). Agustus 14, 2020. http://eprints.ums.ac.id

Pratiwi, A., Jadmiko, A. W., \& Widodo, A. (2017). Modification Of The Psychiatric Emergency Patient Acuity Tool Within A Triage System In An Emergency Unit. Advanced Science Letters, 23(12), 12559-12562. Maret 6, 2020. "https://doi.org/10.1166/asl.2017.10816

Pujiharti, I., \& Widiastuti, T. A. (2017). Hubungan Antara Tingkat Pengetahuan Perawat Tentangproses Keperawatan Dengan Pendokumentasian Asuhan Keperawatan Di Ruang Rawat Inap Rs 
Jati Sampurna Bekasi Tahun 2017. Afiat, 3(2), 365-378.

Putri, P. M. D. (2016). Pengantar Riset Keperawatan. Konsep dan Aplikasi Riset dalam Keperawatan. Yogyakarta: Penerbit Pustaka Biru Press.

Riskesdas (Riset Kesehatan Dasar). (2019). Laporan Badan Penelitian dan Pengembangan Kesehatan Kementerian RI tahun 2018. Jakarta: Kemenkes RI. Juni29, 2020. https://www.kemkes.go.id

Rizani, K., Kholik, S., \& Permadi, M. B. (2018). Tingkat Pendidikan Dan Lama Kerja Perawat Dengan Pengetahuan Perawat Tentang Resusitasi Jantung Paru Di Ruang Igd Rsud. Dr. Moch. Ansari Saleh Banjarmasin. Jurnal Citra Keperawatan, 6(2), 78-88.

Simanjuntak, P.J., 2011. Manajemen dan Evaluasi Kinerja. Jakarta: Lembaga penerbit Fakultas Ekonomi, Universitas Indonesia.

Siregar, S. (2017). Metode Penelitian Kuantitatif SPSS. Dalam Metode Penelitian Kuantitatif SPSS. Jakarta: Kencana, Prenada Media Grup.

Siagian, S. P. (2014). Manajemen Sumber Daya Manusia. Jakarta : Bumi Aksara.

Sujarweni, V. W. (2014). Metodlogi Penilitian Keperawatan. Yogyakarta

Syamsudin, A., Yusuf, A., \& Mundakir, M. (2020). Gambaran Kepercayaan Diri Perawat dalam Mengatasi Agresi Pasien di Rumah Sakit Jiwa Pemerintah Provinsi Jawa Timur. Jurnal Penelitian Kesehatan"Suara Forikes"(Journal of Health Research" Forikes Voice"), 11(4).November23,2020.http://www.fori kesejournal.

Turangan, T. W. S., Kumaat, L. T., \& Malara, R. (2017). Faktor-faktor yang Berhubungan dengan Pengetahuan Perawat Dalam Menghadapi Cardiac Arrest di RSUP Prof RD Kandou Manado. JURNAL KEPERAWATAN, $5(1)$.

Widodo. (2016) Faktor-Faktor Yang Berhubungan Dengan Pengetahuan Perawat Tentang Penatalaksanaan Asuhan Keperawatan Pasien Dekompensasi Kordis Di Ruang ICVCU. Politeknik Kesehatan Surakarta Jurusan Keperawatan. Jurnal Keperawatan
Global, Volume 1, No2, hlm 55-103. Januari, 2021. http://jurnalkeperawatanglobal.com

WHO (World Health Organization). (2019). Mental Disorders. Jenewa: WHO. Juni 29, 2020. https://www.who.int/newsroom/fact-sheets/detail/mental-disorders

.Yulianti, T. S., \& Wijayanti, W. M. P. (2016). Hubungan Tingkat Pendidikan Dan Tingkat Pengetahuan Tentang Kesehatan Jiwa Dengan Sikap Masyarakat Terhadap Pasien Gangguan Jiwa di RW XX Desa Duwet Kidul, Baturetno, Wonogiri. KOSALA: Jurnal Ilmu Kesehatan, 4(1).

Yusuf, A., Fitryasari, R., Nihayati, H. E., \& Tristiana, R. D. (2016). Kompetensi Perawat Dalam Merawat Pasien Gangguan Jiwa. Jurnal Ners, 11(2), 230239. 